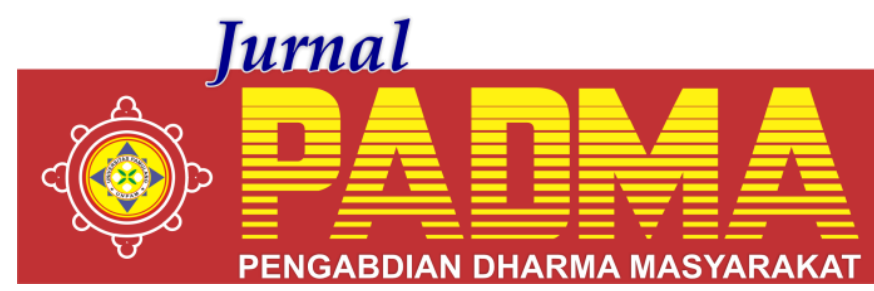

\title{
MENUMBUHKAN SIFAT INOVASI BISNIS DI KALANGAN REMAJA DI MASA PANDEMI COVID-19
}

\author{
${ }^{1 *}$ Yeni Septiani, ${ }^{2}$ Gilang Andriansyah, ${ }^{3}$ Ayu Mustika Anggraeni, ${ }^{4}$ Fazar Nurfadillah, \\ ${ }^{5}$ Feronisa Kurnia Rahma, ${ }^{6}$ Abdul Madjid \\ Universitas Pamulang, Tangerang Selatan, Banten, Indonesia \\ *septiani00723@unpam.ac.id
}

\begin{abstract}
Abstrak
Yayasan Yatim Dhuafa dan Penghafal Al Quran Darul Furqon Ramadhan adalah yayasan yang berada di Jl. Bulak saga No 18 Rt 01 Rw 07 Cibadung Kecamatan Gn. Sindur, Bogor Jawa Barat. Kegiatan pengabdian kepada masyarakat (PKM) ini dilakukan selama 1 (satu) hari yaitu tanggal 23 februari 2020 , kegiatan ini di lakukan dengan pemberian materi dan pembahasan tentang sifat inovasi bisnis di kalangan remaja di masa pandemi. Setelah kegiatan selesai peserta diharapkan dapat memahami materi yang diberikan keterampilan berbisnis dan mampu menjalankan inovasi inovasi bisnis yang telah dipaparkan oleh pemateri.
\end{abstract}

Kata Kunci: Kegiatan, Inovasi

\section{Abstract}

Yayasan Yatim Dhuafa and Penghafal Al Quran Darul Furqon Ramadhan is a foundation located on Jl. Bulak saga No. 18 Rt 01 Rw 07 Cibadung District Gn. Sindur, Bogor West Java. Community service activities (PKM) is carried out for 1 (one) day, namely february 23, 2020, this activity is carried out by providing materials and discussions about the nature of business innovation among adolescents in the pandemic. After the activity is completed participants are expected to understand the materials provided by business skills and be able to carry out business innovation innovations that have been presented by presenters.

Keywords: Activities, Innovation

\section{PENDAHULUAN}

Universitas Pamulang (UNPAM) merupakan kampus yang berdiri di bawah naungan Yayasan Sasmita Jaya. Dalam menjalankan misinya, yaitu melaksanakan pengabdian kepada masyarakat. Dalam implementasinya penelitian berbasis humanis dan religius, UNPAM membuka diri untuk melakukan berbagai pihak dalam rangka peningkatan mutu Pendidikan, pengembangan dalam bidang teknologi informasi dan komunikasi, juga peningkatan citra universitas di mata masyarakat. Pengabdian kepada masyarakat merupakan salah satu dari tri dharma perguruan tinggi yang di lakukan oleh dosen dosen di perguruan tinggi.

Menumbuhkan inovasi dikalangan remaja sangatlah penting apalagi ditengah masa pandemi ini karena inovasi bisnis dapat meningkatkan kegiatan ekonomi dan juga dapat menambah pengetahuan.

\section{METODE}

Demi kelancaran kegiatan ini, maka berikut adalah pelaksana Mahasiswa/i dan diperbantukan oleh Dosen Pembimbing Akademik. Dengan adanya penyampain materi inovasi bisnis menumbuhkan sifat inovasi bisnis dikalangan remaja guna meningkatkan ekonomi di lingkungan sekitar, tetntunya para pebisnis dan pengusaha akan selalu berusaha untuk mencari cara baru dalam meningkatkan bisnis mereka. Mereka harus menemukan cara baru untuk menyelesaikan masalah, meningkatkan produktivitas karyawan, menyaingi para kompetitor dengan sangat baik. Solusi terbaik untuk menyelesaikan semua masalah tersebut adalah mendorong kreativitas yang dimiliki dan berusaha mewujudkan inovasi-inovasi baru.

\section{HASIL DAN PEMBAHASAN}


Menurut Stephen Robbins inovasi adalah semua gagasan atau ide baru yang diterapkan untuk memperbaiki suatu produk dan jasa. Maka dari itu inovasi memiliki peran yang cukup penting ditengah pandemi covid 19. Menurut Everett M. Rogers, inovasi merupakan sebuah ide, gagasan, objek, dan praktik yang dilandasi dan diterima sebagai suatu hal yang baru oleh seseorang atau pun kelompok tertentu untuk di aplikasikan atau pun di adopsi.

Pengertian Inovasi dalam UU Nomor 19 Tahun 2002. Menurut UU No. 19 Tahun 2002, pengertian inovasi adalah kegiatan penelitian, pengembangan, dan atau pun perekayasaan yang dilakukan dengan tujuan melakukan pengembangan penerapan praktis nilai dan konteks ilmu pengetahuan yang baru, atau pun cara baru untuk menerapkan ilmu pengetahuan dan teknologi yang sudah ada ke dalam produk atau pun proses produksinya. Sebuah ide, gagasan, atau pun teori hanya bisa digolongkan ke dalam sebuah inovasi jika memiliki ciri-ciri sebagai berikut: Ciri
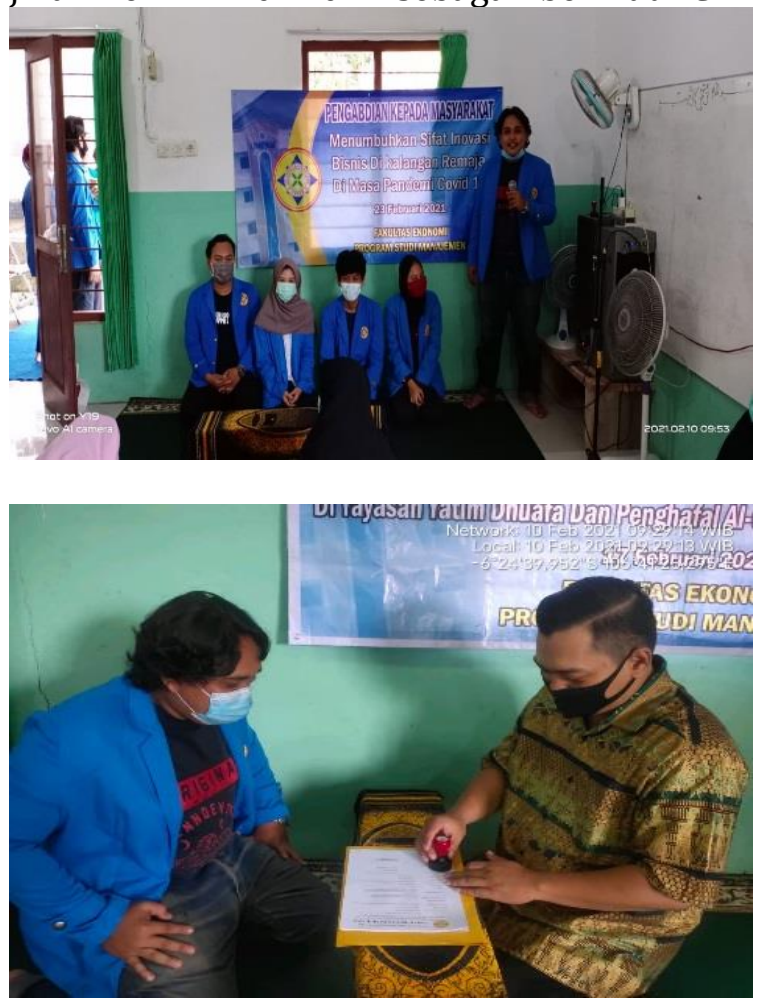

Gambar 1. Foto Selama Kegiatan PKM utama dari sebuah inovasi adalah khas. Inovasi harus memiliki ciri khas sendiri yang tidak dimiliki atau pun ada pada ide atau pun gagasan yang sudah ada sebelumnya. Tanpa ciri khas yang spesifik, sebuah ide atau pun gagasan tidak dapat digolongkan menjadi sebuah inovasi baru. Ciri ke dua dari sebuah inovasi adalah baru. Setiap inovasi harus lah merupakan ide atau pun gagasan baru yang memang belum pernah diungkapkan atau pun dipublikasikan sebelumnya.Ciri ketiga dari sebuah inovasi adalah terencana. Sebuah inovasi biasa nya sengaja dibuat dan direncanakan untuk mengembangkan objekobjek tertentu. Dengan kata lain, setiap inovasi yang ditemukan pada dasar nya merupakan kegiatan yang sudah direncanakan sejak awal. Ciri terakhir yang harus ada pada inovasi adalah memiliki tujuan. Seperti yang telah dijelaskan di poin yang sebelumnya, inovasi merupakan aktivitas terencana untuk mengembangkan objek-objek tertentu (tujuannya adalah mengembangkan objek-objek tertentu).
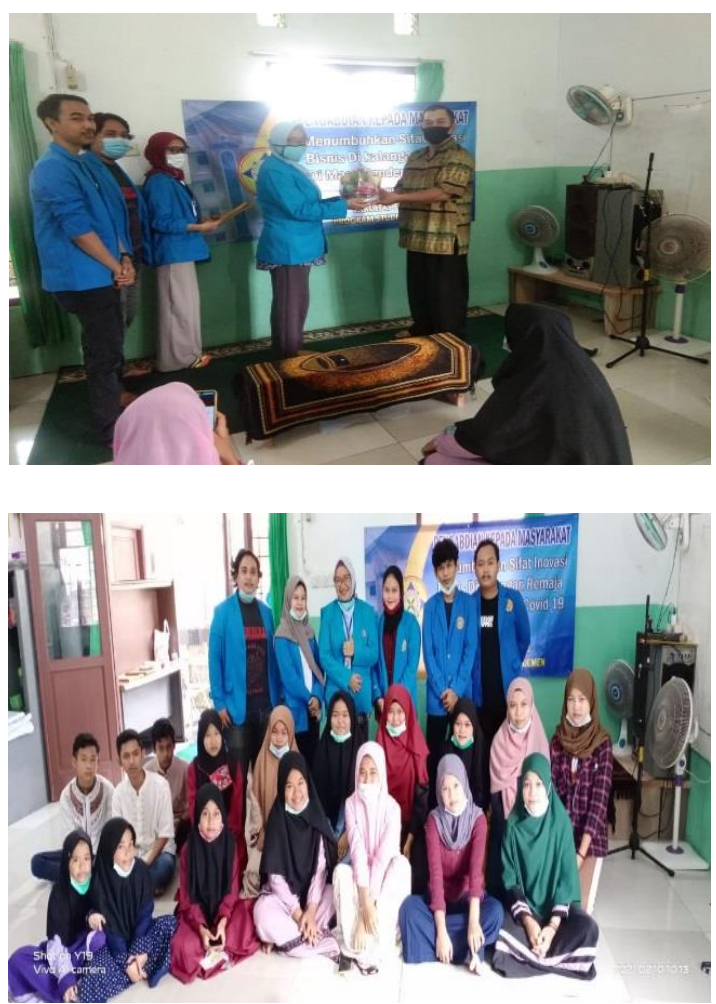

\section{PENUTUP}

Adapun kesimpulan yang dapat kita tarik dari pelaksanaan kegiatan Pengabdian Kepada Masyarakat oleh Universitas Pamulang yang dilakukan oleh kelompok kami telah berjalan dengan lancar dan mendapat sambutan hangat dari tempat pelaksanaan kegiatan ini yaitu Yayasan Yatim Dhuafa dan Penghafal Al-quran darul Furqon Ramadhan. 
Harapan kami dengan pengabdian kepada masyarakat ini dapat membantu Yayasan dalam memberikan pengetahuan tentang menumbuhkan sifat inovasi bisnis di masa pandemi ini. Dalam laporan ini mungkin banyak kekurangan untuk itu kami berharap ada masukan dan kritikkan dalam rangka perbaikan untuk kegiatan kegiatan pengabdian masyarakat dimasa yang akan datang. Semoga kegiatan pengabdian masyarakat ini dapat bermanfaat bagi semua.

Kami ucapkan terimakasih kepada seluruh pihak yang telah mendukung kegiatan yang kami laksanakan dan kami mohon maaf apabila dalam laporan ini banyak ditemukan kekurangan.

\section{DAFTAR PUSTAKA}

Affandi, A., et al (2020). Optimization of MSMEs Empowerment in Facing Competition in the Global Market during the COVID-19 Pandemic Time. Systematic Reviews in Pharmacy, 11(11), 1506-1515.

Gunartin, G., et al. (2020). The Role Analysis of Waste Bank in Improving the Community's Creative Economy (Study at Ketumbar Pamulang Waste Bank). Budapest International Research and Critics Institute (BIRCI-Journal): Humanities and Social Sciences, 3(4), 3262-3269.

Haque, M. G., et al. (2020). Analysis of SMEs Culinary Marketing Strategy During Covid 19 Pancemic: A Study at "Sate Bebek Cilegon" Resto in Cilegon, Banten. International Journal of Education, Information Technology, and Others, 3(2), 447-451.

https://sarjanekonomi.co.id/pengertianinovasi-menurut-para-ahli/

https://www.studilmu.com/blogs/details/p engertian-inovasi-dan-8-hal-pentingmenjadi-inovatif

Nurjaya, N., et al (2021). Pengaruh Etos Kerja Dan Disiplin Kerja Terhadap Kinerja Pegawai Pada Dinas Kehutanan Dan Perkebunan Kota Bogor. JENIUS (Jurnal Ilmiah Manajemen Sumber Daya Manusia), 4(2), 172-184.

Sunarsi, D., et al. (2021). The Influence of Motivation and Work Discipline on Employee Performance at the Yogyakarta Tourism Service. Prosiding ICoGEMT, 1(1), 1-7. 